\title{
Headache as the sole presenting symptom of cerebral venous sinuses thrombosis: Subgroup analysis of data from the VENOST study
}

\author{
Tek semptomu baş ağrısı olan serebral venöz sinüs trombozu: VENOST çalışmasından elde \\ edilen verilerin alt grup analizi
}

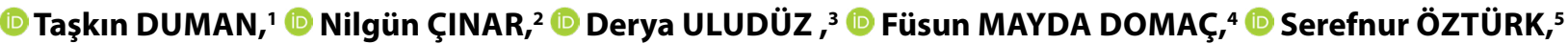

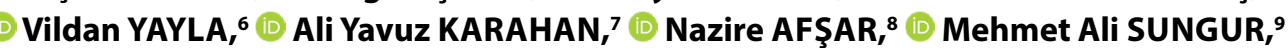

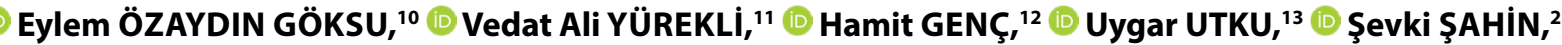

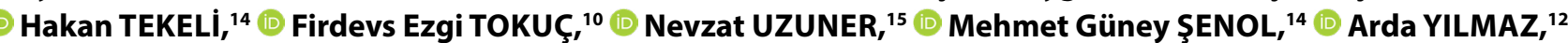

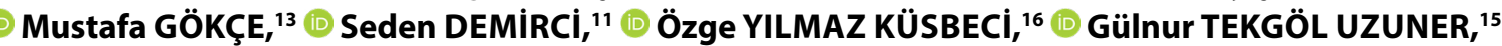
Hale Zeynep BATUR ÇAĞLAYAN, ${ }^{17}$ (1) Mustafa AÇIKGÖZ, ${ }^{18}$ (D) Hatice KURUCU, ${ }^{19}$ (1) Mehmet Fatih ÖZDAĞ, ${ }^{14}$

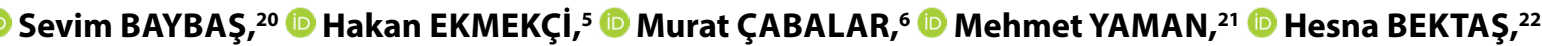

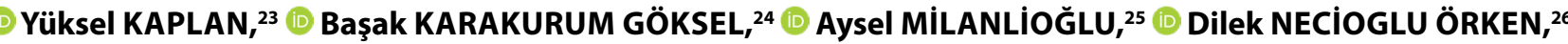

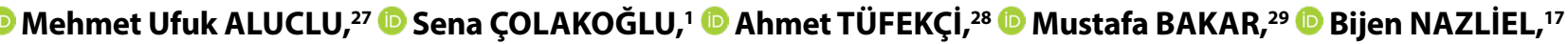
Nida TASÇILAR, ${ }^{18}$ - Baki GÖKSAN, $^{3}$ - Hasan Hüseyin KOZAK, ${ }^{30}$ - Cemile Handan MISIRLI, ${ }^{31}$

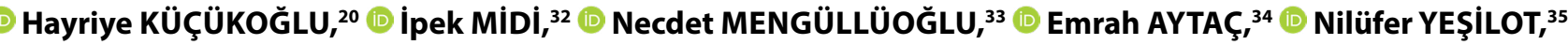
Birsen INCE, ${ }^{3}$ (-) Osman Özgür YALIN, ${ }^{36}$ (D) Taşkın GÜNEŞ, ${ }^{37}$ (1) Serdar ORUÇ, ${ }^{21}$ (i) Serkan DEMIR ${ }^{38}$
\end{abstract}

\footnotetext{
'Department of Neurology, Mustafa Kemal University, Hatay, Turkey; ${ }^{2}$ Department of Neurology, Maltepe University, İstanbul, Turkey; ${ }^{3}$ Department of Neurology, İstanbul Cerrahpaşa University, İstanbul, Turkey; ${ }^{4}$ Department of Neurologic and Psychiatric Diseases, Erenköy Training and Research Hospital for Neurologic and Psychiatric Diseases, İstanbul, Turkey; ${ }^{5}$ Department of Neurology, Selçuk University, Konya, Turkey; ${ }^{6}$ Department of Neurology, Bakırköy Training and Research Hospital, İstanbul, Turkey; ${ }^{7}$ Department of Physical Medicine and Rehabilitation, Uşak University, Uşak, Turkey; ${ }^{8}$ Department of Neurology, Acıbadem University, İstanbul, Turkey; ${ }^{9}$ Department of Biostatistics, Düzce University, Düzce, Turkey; ${ }^{10}$ Department of Neurology, Antalya Training and Research Hospital, Antalya, Turkey; ${ }^{1}$ Department of Neurology, Süleyman Demirel University, Isparta, Turkey; ${ }^{12}$ Department of Neurology, Mersin University, Mersin, Turkey; ${ }^{13}$ Department of Neurology, Kahramanmaraş Sütçü İmam University, Kahramanmaraş, Turkey; ${ }^{14}$ Department of Neurology, Sultan Abdülhamid Han Training and Research Hospital, İstanbul, Turkey; ${ }^{15}$ Department of Neurology, Osmangazi University Faculty of Medicine, Eskişehir, Turkey; ${ }^{16}$ Department of Neurology, Bozyaka Education, Research and Training Hospital, Izmir, Turkey; ${ }^{17}$ Department of Neurology, Gazi University Faculty of Medicine, Ankara, Turkey; ${ }^{18}$ Department of Neurology, Bülent Ecevit University Faculty of Medicine, Zonguldak, Turkey; ${ }^{19}$ Dementia Research Institute, Centre for Discovery Brain Sciences, University of Edinburgh, Edinburgh W1T 7NF, UK; ${ }^{20}$ Department of Neurology, Bakirköy Training and Research Hospital for Neurologic and Psychiatric Diseases, İstanbul, Turkey; ${ }^{21}$ Department of Neurology, Kocatepe University Faculty of Medicine, Afyon, Turkey; ${ }^{22}$ Department of Neurology, Atatürk Training and Research Hospital, Ankara, Turkey; ${ }^{23}$ Department of Neurology, İnonu University Faculty of Medicine, Malatya, Turkey; ${ }^{24}$ Department of Neurology, Başkent University Faculty of Medicine, Adana, Turkey; ${ }^{25}$ Department of Neurology, Yüzüncü Yıl University Faculty of Medicine, Van, Turkey; ${ }^{26}$ Department of Neurology, ístanbul Bilim University Faculty of Medicine, İstanbul, Turkey; ${ }^{27}$ Department of Neurology, Dicle University Faculty of Medicine, Diyarbakır, Turkey; ${ }^{28}$ Department of Neurology, Recep Tayyip Erdoğan University Faculty of Medicine, Rize, Turkey; ${ }^{29}$ Department of Neurology, Uludag University Faculty of Medicine, Bursa, Turkey; ${ }^{30}$ Department of Neurology, Necmettin Erbakan University Faculty of Medicine, Konya, Turkey; ${ }^{31}$ Department of Neurology, Health Sciences University Haydarpaşa Training and Research Hospital, İstanbul, Turkey; ${ }^{32}$ Department of Neurology, Marmara University Faculty of Medicine, Istanbul, Turkey; ${ }^{33}$ Department of Neurology, Eskişehir State Hospital, Eskişehir, Turkey; ${ }^{34}$ Department of Neurology, Ankara Training and Research Hospital, Ankara; ${ }^{35}$ Department of Neurology, İstanbul University, İstanbul Faculty of Medicine, İstanbul, Turkey; ${ }^{36}$ Department of Neurology, Health Sciences University, İstanbul Training and Research Hospital, İstanbul, Turkey; ${ }^{37}$ Department of Neurology, Maltepe State Hospital, i̇stanbul, Turkey, ${ }^{38}$ Department of Neurology, Sancaktepe Şehit Prof. Dr. İlhan Varank Training and Research Hospital, İstanbul, Turkey
}

Submitted (Başvuru tarihi) 16.01.2020 Accepted after revision (Düzeltme sonrası kabul tarihi) 15.04.2020 Available online date (Online yayımlanma tarihi) 11.01.2021

Correspondence: Dr. Nilgün Çınar. Maltepe Üniversitesi Tip Fakültesi, Nöroloji Anabilim Dalı, İstanbul, Turkey

Phone: +90 - 216 - 4429682 e-mail: cinarnilgun@gmail.com

(-) 2021 Turkish Society of Algology 


\section{Summary}

Objectives: Headache is the most common complaint in cerebral venous sinus thrombosis (CVST) and it may sometimes be the only symptom in these patients. This retrospective and prospective study was an investigation of any differences in terms of clinical risk factors, radiological findings, or prognosis in patients with CVST who presented with isolated headache $(\mathrm{IH})$ and cases with other concomitant findings (non-isolated headache $[\mathrm{NIH}]$ ).

Methods: A total of 1144 patients from a multicenter study of cerebral venous sinus thrombosis (VENOST study) were enrolled in this research. The demographic, biochemical, clinical, and radiological aspects of $287 \mathrm{IH}$ cases and $857 \mathrm{NIH}$ cases were compared. Results: There were twice as many women as men in the study group. In the IH group, when gender distribution was evaluated by age group, no statistically significant difference was found. The onset of headache was frequently subacute and chronic in the IH group, but an acute onset was more common in the $\mathrm{NIH}$ group. Other neurological findings were observed in $29 \%$ of the $\mathrm{IH}$ group during follow-up. A previous history of deep, cerebral, or other venous thromboembolism was less common in the IH group than in the NIH group. Transverse sinus involvement was greater in the IH group, whereas sagittal sinus involvement was greater in the $\mathrm{NIH}$ group. The presence of a plasminogen activator inhibitor (PAI) mutation was significantly greater in the IH group.

Conclusion: IH and CVST should be kept in mind if a patient has subacute or chronic headache. PAl, which has an important role in thrombolytic events, may be a risk factor in CVST. Detailed hematological investigations should be considered. Additional studies are needed.

Keywords: Cerebral venous sinus thrombosis; cerebrovascular disease; headache.

\section{Özet}

Amaç: Baş ağrısı serebral venöz sinüs trombozunda (SVST) en sık görülen şikayettir ve bazen CVST ile başvuran hastalarda görülen tek semptom olabilir. Bu retrospektif ve prospektif çalışmada, izole başağrısı (IB) ile başvuran SVST olgularında ve baş ağrısı ile ilişkili diğer bulguları olan (izole olmayan başağrısı-IOBA) olgularda klinik risk faktörleri, radyoloji ve prognoz açısından herhangi bir farklılık olup olmadığını araştırdık.

Gereç ve Yöntem: Serebral venöz sinüs trombozu (VENOST) çok merkezli çalışmasından 1144 hasta çalışmamıza alındı. Tüm demografik, biyokimyasal, klinik ve radyolojik yönler 287 IBA vakası ve 857 IOBA vakası için karşılaştırılmıştır.

Bulgular: Toplam grup içinde kadın oranı iki kat daha yüksekti. İA grubunda cinsiyet dağılımını yaş gruplarına göre değerlendirildiğinde istatistiksel olarak anlamlı bir fark bulunmadı. İA grubunda, baş ağrısının başlangıcı sıklıkla subakut ve kronikti, ancak akut başlangıç, IOBA grubunda daha yaygındı. IBA grubunda\% 29'luk takip sırasında diğer nörolojik bulgular eklenmiştir. Daha önce serebral, derin ve diğer venöz tromboembolizm öyküsü IBA grubunda IOBA grubuna göre daha azdı. Transvers sinüs tutulumu IBA grubunda daha yüksek iken sagital sinüs tutulumu IOBA grubunda daha fazlaydı. Plazminojen aktivatör inhibitörü (PAI) mutasyonu IBA grubunda anlamlı olarak daha yüksekti.

Sonuç: Hastaların subakut veya kronik baş ağrısı varsa SVST tanısı için IBA akılda tutulmalıdır. Trombolitik olaylar için önemli bir role sahip olan PAI, SVST'da bir risk faktörü olabilir, bu nedenle ayrıntılı hematolojik araştırmalar düşünülmelidir. Daha ileri çalışmalara ihtiyaç vardır.

Anahtar sözcükler: Serebrovasküler hastalık; baş ağrısı; serebral venöz sinüs trombozu.

\section{Introduction}

Patients may present with various symptoms as a result of cerebral venous sinus thrombosis (CVST) of dural venous sinuses and deep and superficial cerebral veins thrombosis. ${ }^{[1]}$ CVST can mimic other diseases with different clinical manifestations ranging from headache to coma. CVST may present with a single finding or may be seen as a syndrome consisting of many findings. Clinically unclear process may complicate the diagnosis of CVST. ${ }^{[2,3]}$

In many studies, it has been reported that headache is seen in in more than $80 \%$ of the cases is the most common first symptom. Headache in CVST is not typical and other neurological symptoms such as seizures, papilloedema, focal deficits, cranial nerve paralysis or impaired consciousness can be added to headache. ${ }^{[4]}$

The mechanism of headache in CVST is not known when there is not intracranial hypertension, sub- arachnoid haemorrhage $(\mathrm{SAH})$, meningitis or intracranial lesion.

There is a possibility that nerve fibers are affected in the obstructed sinuses. In addition, it is possible to have contrast involvement around the clot, which is known as the 'empty delta sign' which is a dilatation of the vessels as a result of local inflammation of the sinuses. ${ }^{[4,5]}$

Rarely, headache in CVST may not be associated with any clinical findings. However brain computed tomography (CT) scanning and/or cerebrospinal fluid (CSF) examination usually reveal the conditions such as $\mathrm{SAH}$, intracerebral infarction or haemorrhage that can be the cause of headache of CVST. In the absence of such conditions in CVST, it is rare to have only headache complaints. ${ }^{[6-8]}$

In this study, we presented the characteristics of 1144 patients in whom headache was the only clini- 
cal presentation of CVST in the absence of other aetiological factors which are assessed by imaging tests. Also the aim of this study was to investigate the clues for the diagnosis of CVST only in patients with headache.

\section{Material and Methods}

\section{Patient selection}

The study design of cerebral venous thrombosis (VENOST), an international multicentre observational study involving 1144 patients who were retrospectively diagnosed with CVST between June 2000 and June 2015, was described in detail. ${ }^{[9]}$ The study was approved by the ethics committee of the centers (no: 83045809/604/02-12333).

This study includes all members of the VENOST group. In VENOST, CVST was diagnosed based on the patient's clinical findings and the presence of thrombosis in the cerebral venous sinuses detected using brain computed tomography (CT), brain magnetic resonance imaging (MRI), MR venography (MRV) and/or digital subtraction angiography (DSA).

The patients were divided into two groups according to headaches such as; the cases with CVST that comes with only headache (isolated headache- $\mathrm{IH}$ ) and cases with other findings in addition to headache (non-isolated headache-NIH).

Both groups were compared according to their initial clinical findings on admission, etiologic factors, imaging findings and prognostic factors.

Research on thrombotic risk factors was performed in $63.7 \%$ of the participating centers. ${ }^{[10]}$ Methylenetetrahydrofolate reductase (MTHFR), prothrombin mutation, plasminogen activator inhibitör (PAI) mutation, Factor V Leiden mutation test was performed in 729 patients; Antiphospholipid Ab, hyperhomocysteinemia, hyperfibrinogenemia, antithrombin III and protein $\mathrm{C} / \mathrm{S}$ deficiency, activated protein $\mathrm{C}$ resistance, antinuclear antibody (ANA) positivity, thrombocytosis, anticardiolipin Ab were measured in 941 patients. ${ }^{[9]}$

Etiological risk factors such as infections, systemic inflammatory diseases, rheumatologic or connective tissue diseases, malignancy, hematologic diseases and the other causes were also recorded.
On admission, the duration of symptoms was accepted as acute if the duration is less than 48 hours, subacute between 48 hours and 1 month and chronic if the duration of symptoms was more than 1 month.

Follow-up examination results were classified according to the modified Rankin Scale (mRS). MRS score was classified as $0-1$ independent (favorable outcome), mRS score 2 minimum disability and mRS score 3-6 dependent or dead (poor outcome).

The visits of the cases were recorded 1, 3, 6 and 12 months after the initial diagnosis of CVST.

\section{Results}

Mean age and female/male ratio of $\mathrm{IH}$ group ( $\mathrm{n}$ : 287, $25.1 \%$ ) were $40.1 \pm 13.3$ years and $185 / 102$; $\mathrm{NIH}$ group (n: $857,74.9 \%$ ) were $40.04 \pm 13.8$ years and $592 / 265$ respectively. Statistically meaningful age difference was not detected between $\mathrm{IH}$ and $\mathrm{NIH}$ groups (Table 1).

In the IH group, when evaluated the gender distribution by age groups, there was no statistically significant difference $(p=0.115)$. In the NIH group, the ratio of female/male between the ages of 18-36 was found equal (female/male ratio: $46 / 46 \%$ ), the ratio of female in the 37-50 year-old group was higher (female/male ratio: $37 / 26 \%$ ); in the age group $>50$ years and the ratio of male was significantly higher (female/male oranı: $17 / 28 \%)(p<0.001)$.

In the IH group, onset of headache was frequently subacute and chronic, but an acute onset was more common in the NIH group (Table 1).

Detailed radiological evaluation (MRI and MRV) was performed in $92 \%$ of the $\mathrm{IH}$ group and $88.1 \%$ of the $\mathrm{NIH}$ group. Only MR, MRV, CT + MRV were performed in other cases (Table 1).

It was seen that $10(29 \%)$ patients in $\mathrm{IH}$ group had additional neurological findings including nausea, vomiting, epileptic seizures, visual field defect, focal neurological deficit, altered consciousness and cranial nerve palsies during follow-up. In the $\mathrm{NIH}$ group neurological findings were existed at the beginning

In IH group there was no difference according to existence of parenchymal lesions. In the NIH group, 
parenchymal lesions as infarction, hemorrhage and hemorrhagic transformation were seen more often than the other group (Table 1).

A previous cerebral, deep and other venous thromboembolism history was less common in IH group than the NIH group (Table 2).

Transverse sinus involvement was higher in IH group, whereas sagittal sinus involvement was higher in $\mathrm{NIH}$ group.

The prognosis of IH group was better than $\mathrm{NIH}$ group according to $\mathrm{mRS}$.

When the hematological parameters were examined, plasminogen activator inhibitor (PAI) mutation was significantly higher in IH group (Table 2).

\section{Discussion}

CVST is a complicated process because it may present with different clinical situations. ${ }^{[1]]}$ Rarely CVST may occur with headache alone and there may not always be an additional finding so that CVST may usually be thought to be secondary headache disorders. ${ }^{[12]}$ Headache was reported to be the most common symptom in $92 \%$ of CVST cases in a study. In addition, approximately one-third of patients reported only sole manifestation. ${ }^{[13]}$ In our study, headache was the only onset symptom in one third of the patients. Our results were consistent with the previous studies. In CVST, $84 \%$ of headaches begin as acute to subacute, while $20 \%$ had a chronic onset. ${ }^{[7,14,15]}$ In our IH group, 33\% of CVST cases had chronic type headache.

CVST diagnosis may be made earlier in the patient who comes to the hospital with changes in consciousness, mental disorders and seizures, ${ }^{[7]}$ but care should be taken to avoid misdiagnosis by taking into account the unfamiliar initial pattern in CVST patients with chronic headache. The possibility of CVST should be considered if a chronic intermittent headache worsens or if a new onset chronic headache develops. ${ }^{[14,15]}$ For this reason, patients with subacute or chronic headache should still be examined and venous thrombosis should also be kept in mind. Therefore, detailed radiological evaluation helps in diagnosis and affects treatment positively.
Because of this CT with or without contrast may not be sensitive enough to rule out CVST in patients with headache. The remarkable use of MRI and especially the increase in the use of MRV has made this diagnosis easier. ${ }^{[11]}$ In previous studies, it is shown that MRI combine with MRV are current diagnostic modality of choice and are the best imaging technique for diagnosis of CVST in patients with unclear findings on $C T .{ }^{[16,17]}$ DSA is the more effective for early diagnosis of dural sinüs lesions but the American Heart and Stroke Association recommend MRI and MRV as a preferred tests for the diagnosis of dural sinus lesions. ${ }^{[18]}$ In our study, 92.3\% patients underwent detailed radiological work-ups, including MRI and MRV to put the diagnosis easily.

Patients with CVST may present with variable neurological findings, but usually epileptic seizures, focal neurological deficits and encephalopathy are more common. In a study, focal or generalised seizures occur in $30-50 \%$, papilloedema in $30-60 \%$ of CVST patients approximately $10 \%$ of patients are comatose at the time of diagnosis. ${ }^{[7,9,19]}$ In our study, epileptic seizures, visual field defects, focal neurological deficits were more common in the NIH group and altered consciousness was found to be $24 \%$ of patients.

CVST is usually more common in women than men. In a study it is analyzed that $75 \%$ of patients were women. ${ }^{[20]}$ It is seen more often in middle-aged women. In our study when all 1144 patients were evaluated in terms of gender, women were more in the group. Also, most of them were in the middleaged group.

The cerebral venous system consists of superficial and a deep parts. The superior sagittal and transverse sinuses form the superficial cerebral venous system. Lateral sinus, straight sinus and sigmoid sinus are parts of deeper system. ${ }^{[21]}$ The transverse and superior sagittal sinuses are commonly affected sinuses in CVST. ${ }^{[7]}$ Transverse sinus is the most commonly affected sinus in $77 \%$ of cases in a study. ${ }^{[16]}$ In our study, the most effected sinus was transverse sinus in both groups similar to the other studies. However sagittal sinus involvement was higher in $\mathrm{NIH}$ group than $\mathrm{IH}$ group.

There may be various factors in the etiology of CVST. Genetic and prothrombotic disorders may be among 
Table 1. Compared data of demographical and clinical aspects of both groups

\begin{tabular}{|c|c|c|c|c|c|}
\hline & \multicolumn{2}{|c|}{ Non-isolated headache (NIH) } & \multicolumn{2}{|c|}{ Isolated headache (IH) } & \multirow[t]{2}{*}{$\mathbf{p}$} \\
\hline & $n=857$ & $75 \%$ & $\mathrm{n}=\mathbf{2 8 7}$ & $25 \%$ & \\
\hline Age (years) & \multicolumn{2}{|c|}{$40.04 \pm 13.82$} & \multicolumn{2}{|c|}{$40.15 \pm 13.39$} & 0.911 \\
\hline 18-36 (years) & 397 & 46.3 & 136 & 47.4 & \\
\hline $37-50$ & 292 & 34.1 & 88 & 30.7 & 0.499 \\
\hline$>51$ & 168 & 19.6 & 63 & 22 & \\
\hline \multicolumn{6}{|l|}{ Gender } \\
\hline Female & 592 & 69.1 & 185 & 64.5 & \multirow{2}{*}{0.147} \\
\hline Male & 265 & 30.9 & 102 & 35.5 & \\
\hline \multicolumn{6}{|l|}{ Mode of onset } \\
\hline Acute & 442 & $52.5^{\mathrm{a}}$ & $88^{\mathrm{b}}$ & 31 & \multirow{3}{*}{$<0.001$} \\
\hline Subacute & 280 & $33.3^{\mathrm{a}}$ & $103^{a}$ & 36.3 & \\
\hline Chronic & 120 & $14.3^{\mathrm{a}}$ & $93^{b}$ & 32.7 & \\
\hline \multicolumn{6}{|l|}{ Clinical symptoms and signs } \\
\hline Headache & 710 & 82.8 & 287 & 100 & $<0.001$ \\
\hline Nausea and vomiting & 317 & 37 & 0 & 0 & $<0.001$ \\
\hline Epileptic seizures & 270 & 31.5 & 1 & 0.3 & $<0.001$ \\
\hline Visual field defect & 298 & 34.8 & 5 & 1.7 & $<0.001$ \\
\hline Focal neurological deficit & 207 & 24.2 & 1 & 0.3 & $<0.001$ \\
\hline Altered consciousness & 203 & 23.7 & 1 & 0.3 & $<0.001$ \\
\hline Cranial nerve palsies & 126 & 14.7 & 2 & 0.7 & $<0.001$ \\
\hline \multicolumn{6}{|l|}{ Radiological work-up } \\
\hline Cranial MRI & 50 & 5.9 & 10 & 3.5 & \multirow{4}{*}{0.115} \\
\hline Cranial MRV & 31 & 3.6 & 10 & 3.5 & \\
\hline Cranial MRI+MRV & 752 & 88.1 & 263 & 92.3 & \\
\hline Cranial CT+ MRV & 21 & 2.5 & 2 & 0.7 & \\
\hline \multicolumn{6}{|l|}{ Number of sinuses involved } \\
\hline 1 sinus & 401 & 46.8 & 150 & 52.3 & \multirow{4}{*}{0.185} \\
\hline 2 sinuses & 302 & 35.2 & 85 & 29.6 & \\
\hline 3 sinuses & 125 & 14.6 & 46 & 16 & \\
\hline 4 sinuses & 29 & 3.4 & 6 & 2.1 & \\
\hline \multicolumn{6}{|l|}{ Involved sinuses } \\
\hline Isolated transverse sinuses & 197 & 23 & 95 & 33.1 & 0.001 \\
\hline Isolated sagittal sinuses & 134 & 15.6 & 34 & 11.8 & 0.116 \\
\hline Isolated sigmoid sinuses & 26 & 3 & 11 & 3.8 & 0.508 \\
\hline Isolated cortical veins & 18 & 2.1 & 6 & 2.1 & 0.992 \\
\hline Isolated Juguler sinuses & 12 & 1.4 & 4 & 1.4 & 0.994 \\
\hline Isolated cavernous sinuses & 9 & 1.1 & 0 & 0 & 0.122 \\
\hline Transverse sinuses & 616 & 71.9 & 224 & 78 & 0.041 \\
\hline Sigmoid sinuses & 334 & 39 & 121 & 42.2 & 0.340 \\
\hline Sagittal sinuses & 369 & 43.1 & 76 & 26.5 & $<0.001$ \\
\hline Internal juguler vein & 131 & 15.3 & 47 & 16.4 & 0.659 \\
\hline Cortical veins & 32 & 3.7 & 10 & 3.5 & 0.846 \\
\hline Cavernous sinuses & 15 & 1.8 & 4 & 1.4 & 0.796 \\
\hline \multicolumn{6}{|l|}{ Parenchymal involvement } \\
\hline No lesion & 456 & $53.2^{\mathrm{a}}$ & $229^{b}$ & 79.8 & \multirow{4}{*}{$<0.001$} \\
\hline Infarction & 185 & $21.6^{\mathrm{a}}$ & $33^{b}$ & 11.5 & \\
\hline Hemorrhagic infarction & 180 & $21^{\mathrm{a}}$ & $18^{\mathrm{b}}$ & 6.3 & \\
\hline Intracerebral hemorrhage & 36 & $4.2^{\mathrm{a}}$ & $7^{\mathrm{a}}$ & 2.4 & \\
\hline
\end{tabular}

MRI: Magnetic resonanace imaging; MRV: Magnetic resonance venography; CT: Computed tomography. One-way Anova test: Comparison of a and b: $p \leq 0.05$; comparison of $a$ and $a: p>0.05$. 
Table 2. Etiological factors and outcome according to isolated headache and headache with other etiological factors

\begin{tabular}{|c|c|c|c|c|c|}
\hline & \multicolumn{2}{|c|}{ Isolated headache (-) } & \multicolumn{2}{|c|}{ Isolated headache (+) } & \multirow[t]{2}{*}{$\mathbf{p}$} \\
\hline & $n=857$ & $75 \%$ & $n=287$ & $25 \%$ & \\
\hline \multicolumn{6}{|l|}{ Infections } \\
\hline Paracranial (focal) & 53 & 6.2 & 17 & 5.9 & 0.918 \\
\hline Systemic & 18 & 2.1 & 5 & 1.7 & \\
\hline \multicolumn{6}{|l|}{ History of VTE } \\
\hline Cerebral & 24 & $2.8^{\mathrm{a}}$ & 2 & $0.7^{\mathrm{b}}$ & 0.045 \\
\hline Deep venous thrombosis & 35 & $4.1^{\mathrm{a}}$ & 6 & $2.1^{\mathrm{a}}$ & 0.712 \\
\hline Other & 7 & $0.8^{\mathrm{a}}$ & 1 & $0.3^{\mathrm{a}}$ & 0.075 \\
\hline Malignancy & 43 & 5.0 & 16 & 5.6 & \\
\hline Family history VTE & 11 & 1.3 & 0 & 0 & 0.168 \\
\hline \multicolumn{6}{|l|}{ MTHFR mutation } \\
\hline Heterozygote & 28 & 5 & 9 & 5.3 & 0.254 \\
\hline Homozygote & 30 & 5.4 & 16 & 9.4 & 0.802 \\
\hline Hyperhomocysteinemia & 31 & 4.3 & 14 & 6.2 & 0.133 \\
\hline Prothrombin mutation & 15 & 2.7 & 4 & 2.3 & 0.599 \\
\hline Protein C/S deficiency & 40 & 5.6 & 7 & 3.1 & 0.765 \\
\hline Factor $\mathrm{V}$ leiden mutation & 27 & 4.8 & 10 & 5.8 & 0.692 \\
\hline Thrombocytosis & 8 & 1.1 & 2 & 0.9 & 0.634 \\
\hline Polisitemia vera & 6 & 0.8 & 1 & 0.4 & $<0.001$ \\
\hline Anticardiolipin Ab & 4 & 0.6 & 2 & 0.9 & 0.345 \\
\hline PAl mutation & 2 & 0.4 & 8 & 4.7 & 0.583 \\
\hline Antithrombin III deficiency & 5 & 0.7 & 0 & 0 & 0.744 \\
\hline Hyperfibrinogenemia & 3 & 0.4 & 0 & 0 & 0.819 \\
\hline Antiphospholipid Ab & 9 & 1.3 & 2 & 0.9 & \\
\hline Activated protein $C$ resistance & 11 & 1.5 & 3 & 1.3 & 0.291 \\
\hline High ANA titers & 18 & 2.5 & 3 & 1.3 & 0.11 \\
\hline Behçet disease & 74 & 8.8 & 34 & 12.8 & 0.402 \\
\hline SLE & 12 & 1.4 & 3 & 1.1 & \\
\hline \multicolumn{6}{|l|}{$1^{\text {st }}$ month } \\
\hline $0-1$ & 569 & $73.6^{\mathrm{a}}$ & 218 & $94.4^{b}$ & \\
\hline 2 & 110 & $14.2^{\mathrm{a}}$ & 7 & $3^{b}$ & $<0.001$ \\
\hline$\geq 3$ & 94 & $12.2^{\mathrm{a}}$ & 6 & $2.6^{\mathrm{b}}$ & \\
\hline \multicolumn{6}{|l|}{$3^{\text {rd }}$ month } \\
\hline $0-1$ & 562 & $86.3^{\mathrm{a}}$ & 202 & $97.1^{\mathrm{b}}$ & \\
\hline 2 & 51 & $7.8^{\mathrm{a}}$ & 3 & $1.4^{\mathrm{b}}$ & $<0.001$ \\
\hline$\geq 3$ & 38 & $5.8^{\mathrm{a}}$ & 3 & $1.4^{\mathrm{b}}$ & \\
\hline \multicolumn{6}{|l|}{$6^{\text {th }}$ month } \\
\hline $0-1$ & 526 & $89.5^{\mathrm{a}}$ & 186 & $97.9^{\mathrm{b}}$ & \\
\hline 2 & 36 & $6.1^{\mathrm{a}}$ & 1 & $0.5^{\mathrm{b}}$ & 0.001 \\
\hline$\geq 3$ & 26 & $4.4^{\mathrm{a}}$ & 3 & $1.6^{\mathrm{a}}$ & \\
\hline \multicolumn{6}{|l|}{$12^{\text {th }}$ month } \\
\hline $0-1$ & 481 & $91.3^{\mathrm{a}}$ & 162 & $98.8^{\mathrm{b}}$ & \\
\hline 2 & 22 & $4.2^{\mathrm{a}}$ & 0 & $0^{\mathrm{b}}$ & 0.004 \\
\hline$\geq 3$ & 24 & $4.6^{\mathrm{a}}$ & 2 & $1.2^{\mathrm{a}}$ & \\
\hline
\end{tabular}

ANA: Anti nuclear antibody; MTHFR: Methylenetetrahydrofolate reductase; PAl: Plasminogen activator inhibitor; VTE: Venous thromboembolism; SLE: Systemic Lupus Erytematosus. One-way Anova test: Comparison of a and b: $p \leq 0.05 ;$ comparison of a and a: $p>0.05$. 
the causes of CVST. ${ }^{[22]}$ In a study, after a detailed examination of patients with cerebral venous thrombosis, $20-35 \%$ remains idiopathic. ${ }^{[23]}$ In our study, $44 \%$ of the $\mathrm{IH}$ group and $53 \%$ of the $\mathrm{NIH}$ group had no cause of thrombosis. It is shown that $85 \%$ of affected patients have at least one risk factor. Among the affected patients, $34 \%$ had a prothrombotic condition and $22 \%$ had genetic predisposition to the disease. ${ }^{[6]}$ Common hereditary factors are deficiency of antithrombin III, protein C or protein S, activated protein $C$ resistance and prothrombin 20211 A mutation. ${ }^{[24]}$ Rare defects include heparin cofactor II, plasminogen or tissue plasminogen activator deficiency, PAl-1 and dysfibrinogenemia. ${ }^{[25]}$ In our study, 37\% in the IH group and $42 \%$ in the NIH group had prothrombotic conditions. Also, Behçet's disease was the most common cause of prothrombotic disease in both groups. ${ }^{[10]}$ As an interesting finding, the PAI mutation was significantly higher in the $\mathrm{IH}$ group. PAl is mainly important in regulating the fibrinolytic system. PAI-1 deficiency can cause abnormal bleeding in humans. Excessive release of PAI-1 may disrupt the normal fibrin formation mechanism in the vessel wall, leading to excessive accumulation of fibrin, resulting in thrombotic events. ${ }^{[22,26]}$ PAI-1 genotype polymorphism expresses PAI- 1 at a higher rate and has a higher risk of deep vein thrombosis. ${ }^{[27]}$ In our study, we found that the PAI mutation in IH group was significantly higher than in the other group, but it should be supported by further studies.

It is reported that the outcomes of CVST were positive in $92 \%$ of the patients and the mortality rate was reported as $5.4 \%{ }^{[28]}$ Causes of poor prognosis include systemic or central nervous system infections and treatment inadequacies. ${ }^{[29]}$

In our patients, the prognosis was good in both groups but it was better in the IH group.

\section{Conclusion}

CVST should be remembered in patients with only headache symptom, even if headache is subacute or chronic type. Therefore, MRI and MRV should be added to detailed radiological examinations. PAl, which has an important role for thrombolytic events, may be a risk factor in CVST. PAI mutation should be kept in mind in the evaluation for prothrombotic agents. Further studies are needed.
Ethics Committee Approval: The Istanbul University, Cerrahpaşa Faculty of Medicine Clinical Research Ethics Committee granted approval for this study (date: 06.05.2014, number: 83045809/604/02-12333).

\section{Conflict-of-interest issues regarding the authorship or article: None declared.}

Peer-rewiew: Externally peer-reviewed.

\section{References}

1. Bushnell C, Saposnik G. Evaluation and management of cerebral venous thrombosis. Continuum (Minneap Minn) 2014;20(2):335-51. [CrossRef]

2. Aoun SG, Rahme RJ, Batjer HH, Bendok BR. New guidelines for the management of cerebral venous thrombosis. Neurosurgery 2011;69(2):N15-7. [CrossRef]

3. Paciaroni M, Palmerini F, Bogousslavsky J. Clinical presentations of cerebral vein and sinus thrombosis. Front Neurol Neurosci 2008;23:77-88. [CrossRef]

4. Cumurciuc R, Crassard I, Sarov M, Valade D, Bousser MG. Headache as the only neurological sign of cerebral venous thrombosis: a series of 17 cases. J Neurol Neurosurg Psychiatry 2005;76(8):1084-7. [CrossRef]

5. Shintani S, Murase H, Ota H, Tsukagoshi H, Shiozawa Z. "Pseudo-delta sign" on computed tomography in an extremely acute stage of superior sagittal sinus thrombosis-a case report. Angiology 1990;41(5):417-20. [CrossRef]

6. Ferro JM, Canhão P, Stam J, Bousser MG, Barinagarrementeria F; ISCVT Investigators. Prognosis of cerebral vein and dural sinus thrombosis: results of the International Study on Cerebral Vein and Dural Sinus Thrombosis (ISCVT). Stroke 2004;35(3):664-70. [CrossRef]

7. Ferro JM, Canhão P. Cerebral venous sinus thrombosis: update on diagnosis and management. Curr Cardiol Rep 2014;16(9):523. [CrossRef]

8. Gulati D, Strbian D, Sundararajan S. Cerebral venous thrombosis: diagnosis and management. Stroke 2014;45(2):e168. [CrossRef]

9. Duman T, Uluduz D, Midi I, Bektas H, Kablan Y, Goksel BK, et al; VENOST Study Group. A Multicenter Study of 1144 Patients with Cerebral Venous Thrombosis: The VENOST Study. J Stroke Cerebrovasc Dis 2017;26(8):1848-57.

10. Uluduz D, Midi I, Duman T, Colakoglu S, Tüfekci A, Bakar M, et al. Behçet's disease as a causative factor of cerebral venous sinus thrombosis: subgroup analysis of data from the VENOST study. Rheumatology (Oxford) 2019;58(4):600-8.

11. Ravishankar K. Incidence and pattern of headache in cerebral venous thrombosis. J Pak Med Assoc 2006;56(11):5614.

12. Alvis-Miranda HR, Milena Castellar-Leones S, Alcala-Cerra G, Rafael Moscote-Salazar L. Cerebral sinus venous thrombosis. J Neurosci Rural Pract 2013;4(4):427-38. [CrossRef]

13. Sparaco M, Feleppa M, Bigal ME. Cerebral Venous Thrombosis and Headache--A Case-Series. Headache 2015; 55(6):806-14. [CrossRef]

14. Luo Y, Tian X, Wang X. Diagnosis and Treatment of Cere- 
bral Venous Thrombosis: A Review. Front Aging Neurosci 2018;10:2. [CrossRef]

15. Uzar E, Ekici F, Acar A, Yucel Y, Bakir S, Tekbas G, et al. Cerebral venous sinus thrombosis: an analyses of 47 patients. Eur Rev Med Pharmacol Sci 2012;16(11):1499-505.

16. Anadure RK, Wilson V, Sahu S, Singhal A, Kota S. A study of clinical, radiological and etiological profile of cerebral venous sinus thrombosis at a tertiary care center. Med J Armed Forces India 2018;74(4):326-32. [CrossRef]

17. Issar $P$, Chinna S, Issar SK. Evaluation of Cerebral Venous Thrombosis by CT, MRI and MR Venography. J Assoc Physicians India 2017;65(11):16-21.

18. Saposnik G, Barinagarrementeria F, Brown RD Jr, Bushnell CD, Cucchiara B, Cushman M, et al; American Heart Association Stroke Council and the Council on Epidemiology and Prevention. Diagnosis and management of cerebral venous thrombosis: a statement for healthcare professionals from the American Heart Association/American Stroke Association. Stroke 2011;42(4):1158-92. [CrossRef]

19. Silvis SM, de Sousa DA, Ferro JM, Coutinho JM. Cerebral venous thrombosis. Nat Rev Neurol 2017;13(9):555-65.

20. Coutinho JM, Ferro JM, Canhão $P$, Barinagarrementeria F, Cantú C, Bousser MG, et al. Cerebral venous and sinus thrombosis in women. Stroke 2009;40(7):2356-61. [CrossRef]

21. Kiliç T, Akakin A. Anatomy of cerebral veins and sinuses. Front Neurol Neurosci 2008;23:4-15. [CrossRef]

22. Bindala S, Coskun O, Alioglu B, Inan LE, Sahin BE, Ocal R.
Elevation of Blood Plasminogen Activator Inhibitor Level in Patients With Cerebral Venous Thrombosis. J Neurol Res 2018;8(1-2):4-9. [CrossRef]

23. Maksimova MY, Dubovitskaya Yl, Shuvakhina NA. Clinical presentations, diagnosis and treatment of cerebral vein and sinus thrombosis. Zh Nevrol Psikhiatr Im S S Korsakova 2018;118(3. Vyp. 2):3-8. [Article in Russian] [CrossRef]

24. Pai N, Ghosh K, Shetty S. Hereditary thrombophilia in cerebral venous thrombosis: a study from India. Blood Coagul Fibrinolysis 2013;24(5):540-3. [CrossRef]

25. Akhtar N, Deleu D, Kamran S. Haematologic disorders and cerebral venous thrombosis. J Pak Med Assoc 2006;56(11):498-501.

26. Koenig W. Haemostatic risk factors for cardiovascular diseases. Eur Heart J 1998;19(Suppl C):C39-43.

27. Seguí R, Estellés A, Mira Y, España F, Villa P, Falcó C, et al. PAl1 promoter $4 \mathrm{G} / 5 \mathrm{G}$ genotype as an additional risk factor for venous thrombosis in subjects with genetic thrombophilic defects. Br J Haematol 2000;111(1):122-8. [CrossRef]

28. Zuluaga MI, Massaro M, Franco CA. Cerebral venous sinus thrombosis: Epidemiology, clinical characteristics, imaging and prognosis. Biomedica 2015;35(2):196-203. [Article in Spanish]

29. Karsy M, Harmer JR, Guan J, Brock AA, Ravindra VM, Chung LS, et al. Outcomes in adults with cerebral venous sinus thrombosis: A retrospective cohort study. J Clin Neurosci 2018;53:34-40. [CrossRef] 